\title{
ANALISIS HUBUNGAN ANTARA KECERDASAN LOGIS MATEMATIS DENGAN KEMAMPUAN KOMUNIKASI MATEMATIS SISWA
}

\author{
Faridah Bahiyatun Nisa1, Mohammad Mukhlis², Maswar Maswar ${ }^{3}$ \\ 1Program Studi Tadris Matematika Institut Agama Islam Negeri Jember \\ 2Institut Agama Islam Negeri Jember, Indonesia \\ ${ }^{3}$ Universitas Ibrahimy, Situbondo, Indonesia \\ faridahnisa025@gmail.com
}

\begin{abstract}
:
This study examined the relationship of logical intelligence students' mathematical communication skills. This research was conducted at the senior high school of Jenggawah at the even semester of the 2019/2020 academic year. The population in this study were all of the high school students of class X IPA, the total students were 144 students in the 2019/2020 academic year. The sampling technique of this study was using 64 Randoms Cluster Sampling as well as the instruments used in the form of mathematical logical intelligence questionnaire and mathematical communication skills test questions. The Analysis of the data used in this research was descriptive and inferential analysis by using a simple linear regression test. Based on the results of a simple linear regression test that the results of the relationship of mathematical logical intelligence of mathematical communication skills can be seen from $t$ count $=11.074>t$ table $=1.997$ with a significance of 0.000 $<0.05$, it could be concluded that there was a relationship of mathematical logical intelligence to mathematical communication ability.
\end{abstract}

Keywords: Intelligence, mathematical logical, ability, mathematical communication.

\section{PENDAHULUAN}

Pada Era Revolusi Industri 4.0, tentunya menuntut seseorang akan banyak hal yang sangat kompleks untuk dikuasai baik di bidang Science, Tekhnology, Engineering and Mathematics (STEM). Pada dasarnya, STEM ini merupakan salah satu upaya yang diproyeksikan untuk merevolusi pembelajaran di masa depan. STEM juga merupakan kurikulum pendidikan yang sangat berfokus pada mata pelajaran Sains, Tekhnologi, Teknik dan Matematika (Agustina, Kaniawati, \& Suwarma, 2017). Di antara keempat dasar ilmu pengetahuan yang harus dimiliki, matematika adalah disiplin ilmu yang sangat elementer, matematika merupakan ilmu yang berhubungan dengan numerasi, pola perubahan, hubungan, ruang dan bentuk. Matematika juga didefinisikan sebagai disiplin ilmu yang bersifat abstrak dan penuh dengan pemecahan masalah yang rumit.

Probondani (2016) mengatakan bahwa salah satu tujuan pembelajaran pemecahan masalah matematika adalah untuk mendorong siswa agar terampil dalam proses berfikir kritis, rasional dan logis matematis. Hasil penelitian yang dilakukan oleh Saiful, Hobri, \& Tohir (2020) menunjukkan bahwa siswa telah melibatkan semua metakognisinya dengan baik ketika ketika memecahkan masalah matematika, dengan dapat menggunakan komponen metakognisi. Menurut Munawwarah, Laili, \& Tohir (2020) mengatakan bahwa pemecahan 
masalah matematika adalah kesanggupan siswa untuk dapat memahami masalah melalui identifikasi unsur-unsur yang diketahui, dinyatakan dan kecukupan unsur yang diperlukan, membuat atau menyusun strategi penyelesaian dan merepresentasikannya, memilih atau menerapkan strategi pemecahan untuk mendapatkan solusi, dan memeriksa kebenaran solusi dan merefleksikannya. Menurut Tohir, Maswar, Atikurrahman, Saiful, \& Pradita (2020) mengatakan bahwa suatu masalah tertentu dikatakan masalah matematika apabila masalah tersebut mengandung konsep matematika yang dalam penyelesaiannya membutuhkan cara tidak langsung.

Berkenaan dengan kecerdasan logis matematis siswa dalam menyelesaikan soal matematika, Mukarromah (2019) menyatakan bahwa kecerdasan logis matematis adalah gabungan dari tingkat perhitungan secara sistematis dan bernalar. Kecerdasan logis matematis sangat berkaitan dengan matematika karena lebih mengutamakan kemampuan berhitung dan logika. Hal ini relevan dengan pernyataan Novitasari \& Abdul Rahman (2015) bahwa seseorang yang memiliki kecerdasan logis matematis akan melibatkan kemampuan untuk menganalisis suatu masalah, menemukan atau menciptakan rumus-rumus atau pola matematika dan menyelidiki masalah secara ilmiah dalam memecahkan masalah matematika. National Council Teacher of Mathematics (NCTM) menetapkan standar-standar kemampuan matematis ialah seperti pemecahan masalah, penalaran dan pembuktian, koneksi, representasi dan komunikasi matematis (Siagian, 2016). Sedangkan menurut Tohir, Abidin, Dafik, \& Hobri (2018), kemampuan berpikir dalam mengidentifikasi dan membangun rumus dalam matematika diperlukan untuk menumbuhkan pemahaman siswa pada materi dan menghasilkan pembelajaran yang bermakna.

Kecerdasan logis matematis siswa diasumsikan memiliki dapak positif terhadap kemampuan komunikasi matematis siswa. Menurut Senjayawati (2015), komunikasi matematika terbagi menjadi dua hal yaitu komunikasi secara tulisan dan komunikasi secara lisan. Pada penelitian ini, kemampuan komunikasi matematis yang diamati hanyalah kemampuan komunikasi matematis secara tulisan (Endriani, Mirza, \& Nursang, 2017). Sehingga, tujuan dalam penelitian ini adalah untuk mengetahui hubungan antara kecerdasan logis matematis dan kemampuan komunikasi matematis siswa dalam memecahkan masalah matematika pada materi Sistem Persamaan Linear Tiga Variabel (SPLTV).

Hasil penelitian sebelumnya dilakukan oleh Budiyanto (2018) menunjukkan bahwa: (1) kecerdasan logis matematis siswa kelas X SMA Parwayatan Daha berkategori sedang, (2) kemampuan pemecahan masalah matematis siswa kelas $\mathrm{X}$ SMA Parwayatan Daha dalam menyelesaikan soal cerita SPLDV berkategori cukup, (3) tidak ada pengaruh kecerdasan logis matematis terhadap kemampuan pemecahan masalah matematis dalam menyelesaikan soal cerita SPLDV.

Berdasarkan uraian di atas, maka dapat disimpulkan bahwa belum ada yang meneliti tentang hubungan antara kecerdasan logis matematis dengan kemampuan komunikasi matematis siswa. Oleh karena itu, peneliti tertarik untuk mengetahui lebih mendalam keterkaitan antara kecerdasan logis matematis dengan kemampuan komunikasi matematis. Hal tersebut diperkuat dengan hasil observasi awal yang dilakukan di SMAN Jenggawah khususnya pada kelas X IPA. Siswa di kelas $\mathrm{X}$ IPA merupakan kelas yang mempunyai kecerdasan logis 
matematis yang tinggi, namun dalam hal mengkomunikasikan permasalahan tersebut, siswa di kelas X IPA terbilang mempunyai tingkat komunikasi matematis yang rendah. Khususnya pada pokok bahasan sistem persamaan linear tiga variabel. Sistem persamaan linear tiga variabel merupakan suatu materi di kelas $\mathrm{X}$ IPA semester ganjil SMAN Jenggawah yang terbilang susah karena pada materi tersebut siswa dituntut untuk mengubah soal cerita persamaan linear tiga variabel menjadi model matematika terlebih dahulu baru bisa mencari penyelesaiannya.

\section{METODE PENELITIAN}

Jenis penelitian ini merupakan penelitian asosiatif dengan pendekatan kuantitatif. Sugiyono (2017) penelitian asosiatif adalah penelitian yang dimaksudkan untuk mengetahui hubungan dua variabel atau lebih. Penelitian kuantitatif merupakan suatu pendekatan penelitian yang bertujuan untuk meneliti pada populasi atau sampel tertentu yang dipilih oleh peneliti dalam mengambil sampel secara random atau acak. Mengenai pengambilan sampel, Arikunto (2009) mengatakan bahwa pengambilan sampel yang dapat dilakukan oleh peneliti adalah menggunakan teknik cluster random sampling dimana kelas yang digunakan sebagai populasi di undi, kemudian diambil $25 \%$ dari populasi untuk dijadikan sampel. Sehingga alur dalam penelitian ini adalah sebagai berikut:

Populasi dalam penelitian ini adalah seluruh siswa kelas X IPA SMAN Jenggawah. Sedangkan sampelnya hanya siswa kelas X IPA 3 dan X IPA 4. Teknik penentuan sampel yang digunakan ialah cluster random sampling. Kemduian, teknik pengumpulan data yang digunakan berupa tes dan angket. Soal tes dan aangkat sudah divalidasi oleh 3 orang validator dengan hasil yang valid. Tes digunakan untuk menjaring data penelitian tentang kemampuan komunikasi matematis siswa, sedangkan angket digunakan untuk menjaring data penelitian berupa kecerdasan logis matematis siswa. Sebelum Instrumen tes dan angket dibagikan ke seluruh siswa yang notabene sebagai sampel penelitian, terlebihdahulu instrument tersebut divalidasi oleh dua ahli yang berprofesi sebagai dosen dan satu orang guru mata pelajaran matematika di sekolah tersebut. Kemudian, instrumen tersebut diujicobakan terlebih dahulu pada kelas X IPA 1 dan hasilnya dianalisis dengan menggunakan SPSS 22 for windows, dan menunjukkan bahwa instrumen penelitian valid dan reliabel.

Teknik analisis data yang digunakan dalam penelitian ini adalah analaisis statistik deskriptif yang terdiri dari minimum, maksimum, mean, median, modus, dan jangkauan. Teknik analisis lebih lanjut ialah dengan statistik inferensial, yaitu menggunakan regresi linear sederhana. Menurut Maswar (2017) statistik inferensial adalah teknik yang digunakan untuk melakukan perhitungan terhadap data yang dikumpulkan untuk membuat kesimpulan secara general.

\section{HASIL PENELITIAN}

\section{Analisis Statistika Deskriptif}

Deskripsi umum tentang data hasil penelitian yang diperoleh meliputi kategori dan frekuensi dari masing-masing instrumen dengan uraian sebagai berikut:

a. Data Hasil Angket Kecerdasan Logis Matematis

Alifmatika: Jurnal Pendidikan dan Pembelajaran Matematika, Desember 2020, Vol. 2, No. 2 
Faridah Bahiyatun Nisa, Mohammad Mukhlis, \& Maswar Maswar

Adapun data hasil angket kecerdasan logis-matematis dapat dilihat pada Tabel 1 berikut ini.

Tabel 1. Statistik Perolehan Angket Kecerdasan Logis Matematis

\begin{tabular}{cc}
\hline Deskripsi & Skor \\
\hline Maksimum & 72 \\
Minimum & 42 \\
Rata-Rata & 57,42 \\
Nilai Tengah & 56 \\
Nilai Sering Muncul & 53 \\
Jangkauan & 30 \\
\hline
\end{tabular}

Acuan dari penggunaan Tabel 1 merupakan distribusi frekuensi skor kecerdasan logis matematis dengan tiga kategori dihitung menggunakan peritungan sebagai berikut (Andreani, 2017):

$$
\begin{aligned}
& c=\frac{r}{k} \\
& c=\frac{30}{3}=10
\end{aligned}
$$

Berdasarkan hasil perhitungan di atas dapat diperoleh distribusi frekuensi skor kecerdasan logis matematis yang disajikan pada diagram batang berikut.

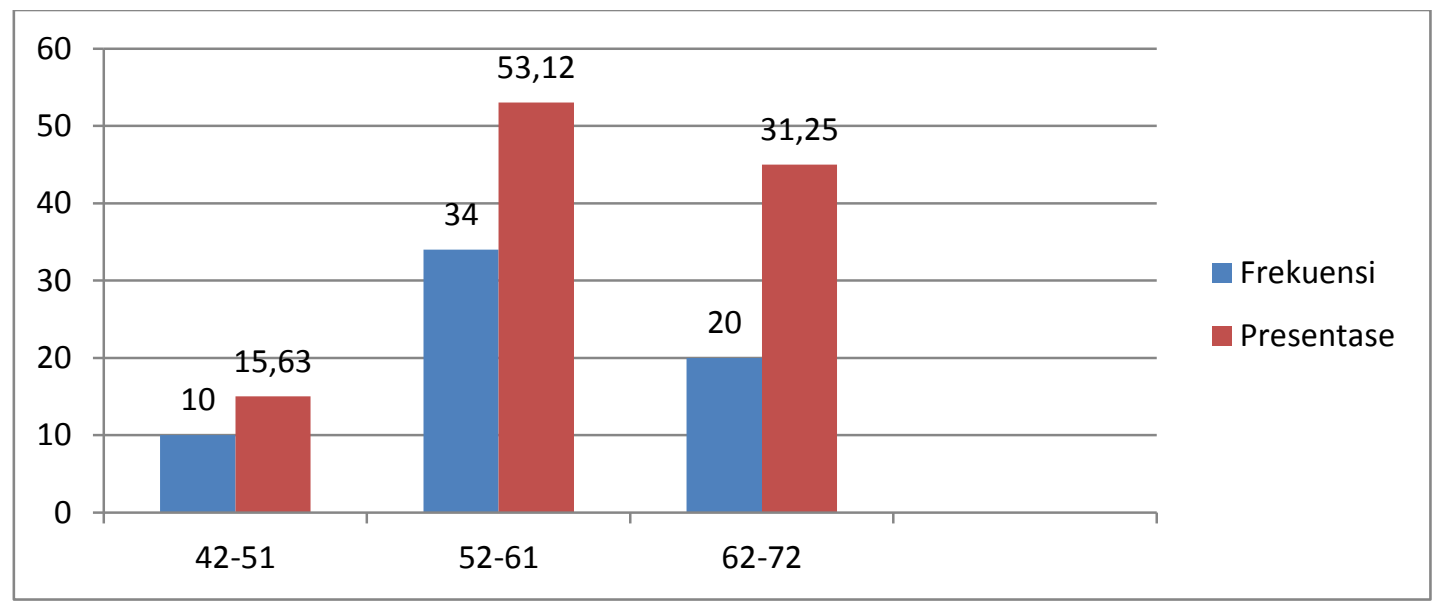

Gambar 1. Diagram Batang Kategori Kecerdasan Logis Matematis

Berdasarkan diagram batang pada Gambar 1 di atas, menunjukkan bahwa tingkat kecerdasan logis-matematis siswa kelas X IPA SMAN Jenggawah Jember berada dalam kategori rendah (42-51) sebesar 15,63\%, kategori sedang (52-61) sebesar $53,12 \%$ dan kategori tinggi (62-72) sebesar 31,25\%.

b. Hasil Tes Kemampuan Komunikasi Matematis

Adapun data hasil tes kemampuan komunikasi matematis dapat dilihat dari Tabel 2 berikut ini.

Alifmatika: Jurnal Pendidikan dan Pembelajaran Matematika, Desember 2020, Vol. 2, No. 2 
Analisis Hubungan Antara Kecerdasan Logis Matematis dengan....

Tabel 2. Statistik Perolehan Tes Kemampuan Komunikasi Matematis

\begin{tabular}{cc}
\hline Deskripsi & Skor \\
\hline Maksimum & 55 \\
Minimum & 0 \\
Rata-Rata & 37,52 \\
Nilai Tengah & 38 \\
Nilai Sering Muncul & 40 \\
Jangkauan & 55 \\
\hline
\end{tabular}

Acuan dari penggunakan Tabel 2 merupakan distribusi frekuensi skor kemampuan komunikasi matematis dengan tiga kategori dihitung menggunakan peritungan sebagai berikut:

$$
\begin{aligned}
& c=\frac{r}{k} \\
& c=\frac{55}{3}=18,3 ; \text { panjang kelas dibulatkan menjadi } 19 .
\end{aligned}
$$

Dari hasil perhitungan di atas dapat diperoleh distribusi frekuensi skor kemampuan komunikasi matematis yang disajikan dalam diagram batang berikut.

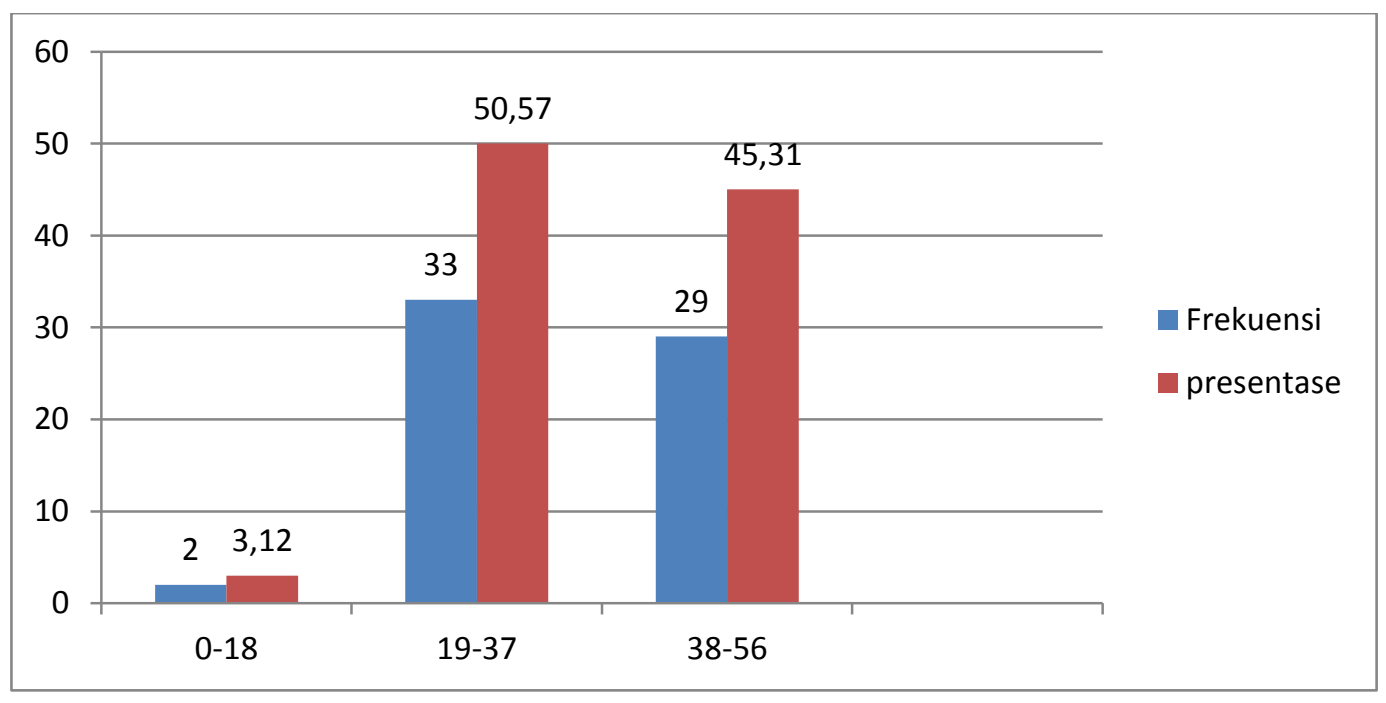

Gambar 2. Diagram Batang Kategori Kemampuan Komunikasi Matematis

Berdasarkan diagram batang pada Gambar 2 di atas, menunjukkan bahwa tingkat kemampuan komunikasi matematis siswa kelas X IPA SMAN Jenggawah Jember berada dalam kategori rendah (0-18) sebesar 3,12\%, kategori sedang (1937 ) sebesar $50,57 \%$ dan kategori tinggi (38-56) sebesar 45,31\%.

\section{Analisis Statistika Inferensial}

Analisis statistika inferensial yang digunakan dalam penelitian ini ialah regresi linear sederhana. terdapat dapat uji prasyarat analisis yang harus dilakukan

Alifmatika: Jurnal Pendidikan dan Pembelajaran Matematika, Desember 2020, Vol. 2, No. 2 
terlebih dahulu sebelum menggunakan analsis tersebut, yaitu uji normalitas dan uji homogenitas.

\section{a. Uji Normalitas}

Uji normalitas digunakan bertujuan untuk menguji sebuah variabel bebas dan variabel terikat, model regresi atau keduanya berdistribusi normal atau tidak. Model regresi yang baik adalah model regresi yang berdistribusi normal.

Uji normalitas peneliti menggunakan Kolmogorov-smirnov yang mana dapat dikatakan normal apabila nilai signifikannya $>0,05$. Dengan perhitungan menggunakan SPSS 22 for Windows untuk data kecerdasan logis matematis terhadap kemampuan komunikasi matematis dikatakan tidak normal karena nilai signifikannya $<0,05$. Apabila terjadi pada sebuah data, dimana data yang digunakan tidak normal, maka peneliti bisa menggunakan opsi kedua yaitu menggunakan tranformasi data (Basuki, 2015). Hasil transformasi data dapat disajikan pada Tabel 3 berikut ini.

Tabel 3. Uji Normalitas antara Kecerdasan Logis Matematis dan Kemampuan Komunikasi Matematis

One-Sample Kolmogorov-Smirnov Test

\begin{tabular}{llcc}
\hline & & $\begin{array}{c}\text { Kecerdasan } \\
\text { Logis }\end{array}$ & $\begin{array}{c}\text { Komunikasi } \\
\text { Matematis }\end{array}$ \\
\hline $\mathrm{N}$ & Mean & 64 & 63 \\
Normal Parameters & & 4.9193 & 7.4544 \\
& Std. & 1.31668 & .50288 \\
& Deviation & .085 & .110 \\
Most Extreme Differences & Absolute & .055 & .110 \\
& Positive & -.085 & -.088 \\
Test Statistic & Negative & .085 & .110 \\
Asymp. Sig. (2-tailed) & & $.200^{\mathrm{c}, \mathrm{d}}$ & $.058^{\mathrm{c}}$ \\
\hline
\end{tabular}

Berdasarkan pengujian $\mathrm{p}$ value kecerdasan logis-matematis pada Tabel 3 diatas menunjukkan bahwa nilai yang didapat sebesar 0,200 >0,05 dan pada kemampuan komunikasi matematis didapat nilai sebesar 0,58 $>0,05$. Oleh karena itu, dapat disimpulkan bahwa data kecerdasan logis-matematis dan data kemampuan komunikasi matematis berdistribusi normal.

\section{b. Uji Heterokesdastisitas}

Uji heterokedastisitas digunakan untuk menguji apakah residual data suatu model regresi estimasi memiliki varians yang konstan atu tidak. Regresi yang bebas dari heterokesdastisitas apabila tidak ada pola yang jelas, serta titik - titik menyebar di atas dan di bawah angka 0 pada sumbu Y. Dari hasil perhitungan menggunakan SPSS 22 for Windows variabel kecerdasan logis matematis terhadap kemampuan komunikasi matematis dapat dilihat pada gambar 4 di bawah ini.

Alifmatika: Jurnal Pendidikan dan Pembelajaran Matematika, Desember 2020, Vol. 2, No. 2 


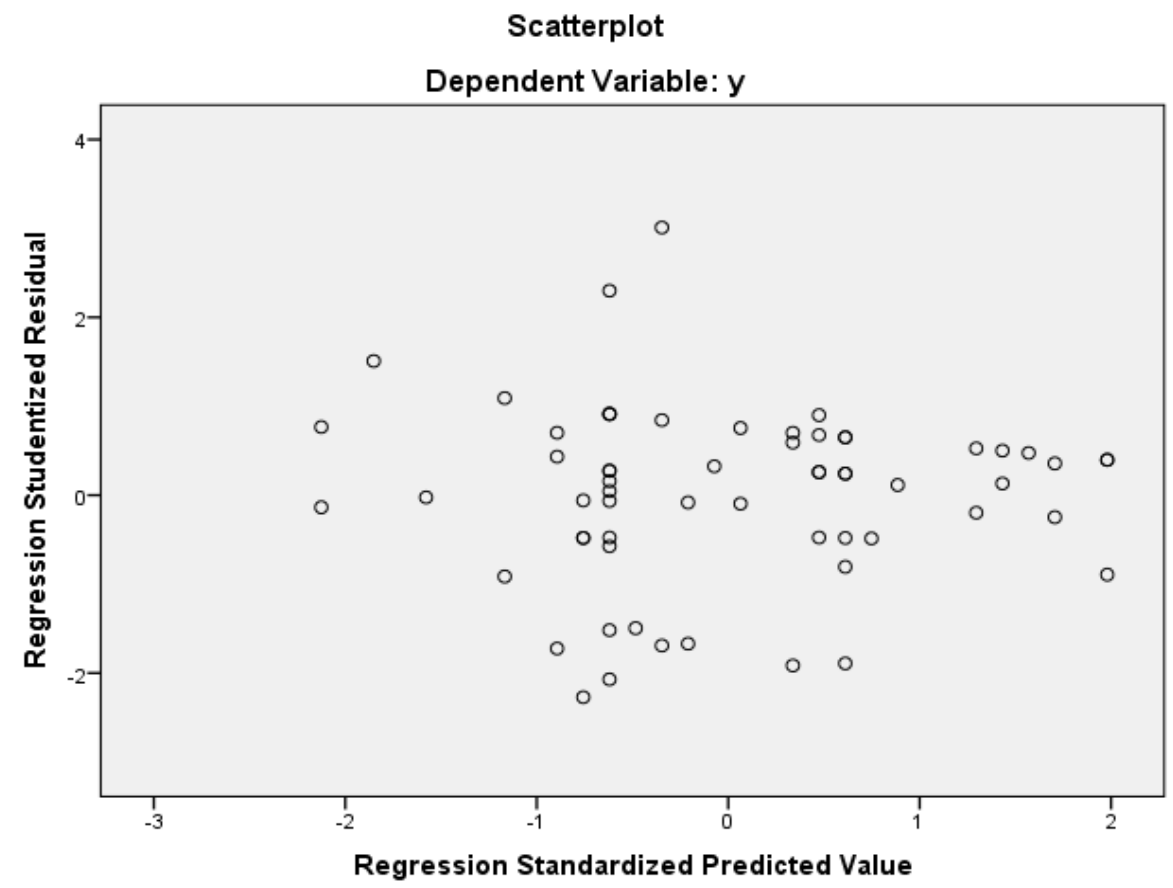

Gambar 3. Heterokedastisitas Kecerdasan Logis Matematis dan Kemampuan Komunikasi Matematis

Berdasarkan Gambar 3 di atas dapat dilihat bahwa tidak terdapat pola yang jelas serta titik - titik menyebar di bawah angka 0 pada sumbu Y, maka dapat disimpulkan bahwa tidak terjadi heterokesdastisitas. Untuk memastikan lagi data peneliti terjadi heterokesdastisitas atau tidak. Peneliti menggunakan heterokesdastisitas glatser yang mana dapat dilihat dari nilai signifikannya. Dikatakan tidak terjadi heteroskedastisitas memakai uji glatser apabila nilai signifikansi $>0,05$.

Tabel 4. Heterokesdastisitas Kecerdasan Logis Matematis dan Kemapuan Komunikais Matematis

Coefficients $^{\mathrm{a}}$

\begin{tabular}{|c|c|c|c|c|c|c|c|}
\hline \multirow{2}{*}{ Model } & \multicolumn{2}{|c|}{$\begin{array}{l}\text { Unstandardized } \\
\text { Coefficients }\end{array}$} & \multirow{2}{*}{$\begin{array}{c}\text { Standardized } \\
\text { Coefficients } \\
\text { Beta }\end{array}$} & \multirow{2}{*}{$\mathrm{t}$} & \multirow{2}{*}{ Sig. } & \multicolumn{2}{|c|}{$\begin{array}{c}\text { Collinearity } \\
\text { Statistics }\end{array}$} \\
\hline & $\mathrm{B}$ & $\begin{array}{l}\text { Std. } \\
\text { Error }\end{array}$ & & & & Tolerance & VIF \\
\hline (Constant) & .435 & .152 & & 2.860 & .006 & & \\
\hline X & -.005 & .003 & -.219 & -1.742 & .087 & 1.000 & 1.000 \\
\hline
\end{tabular}

a. Dependent Variable: RES2

Berdasarkan data pada Tabel 4 di atas menunjukkan bahwa nilai signifikansi 0,87 > 0,05 dinyatakan bahwa data ini tidak terjadi heteroskedastisitas dan dapat dilanjutkan untuk uji regresi linear sederhana.

Alifmatika: Jurnal Pendidikan dan Pembelajaran Matematika, Desember 2020, Vol. 2, No. 2 


\section{Pengujian Hipotesis}

Penelitian ini bertujuan untuk mengetahui hubungan antara kecerdasan logis matematis dan kemampuan komunikasi matematis siswa dalam menyelesaikan SPLTV. Analisis yang digunakan dalam penelitian ini adalah regresi linear sederhana dengan berbantuan SPSS 22 for Windows.

Analisis regresi linear sederhana ini dimaksudkan untuk mengetahui ada tidaknya hubungan yang signifikan antara kecerdasan logis matematis dengan kemampuan komunikasi matematis. Selain itu, model regresi dapat digunakan untuk melakukan prediksi nilai masa medatang (future value) pada variabel dependen didasarkan pada nilai masa sekarang (present value) pada variabel independennya. Pengambilan keputusan dalam pengujian hipotesis penelitian yaitu dinyatakan signifikan apabila $t_{\text {hitung }}>t_{\text {tabel }}$ pada taraf signifikansi 0,05 maka $\mathrm{H}_{\mathrm{a}}$ diterima dan $\mathrm{H}_{0}$ ditolak dan jika $\mathrm{t}_{\text {hitung }} \leq \mathrm{t}_{\text {tabel }}$ maka $\mathrm{H}_{\mathrm{a}}$ ditolak dan $\mathrm{H}_{0}$ diterima. Adapun rekapitulasi hasil regresi linear sederhana kecerdasan logis matematis terhadap kemampuan komunikasi matematis dapat dilihat pada Tabel 5 berikut ini.

Tabel 5. Rekapitulasi Hasil Regresi Linear Sederhana

\begin{tabular}{|c|c|c|c|c|c|c|c|}
\hline $\begin{array}{c}\text { Variabel } \\
\text { Bebas }\end{array}$ & $\begin{array}{c}\text { Variabel } \\
\text { Terikat }\end{array}$ & $\begin{array}{l}\text { Constan } t \\
\text { (a) }\end{array}$ & $\begin{array}{l}\text { Koefesien } \\
\text { Regresi b }\end{array}$ & thitung & $t_{\text {tabel }}$ & Probabilitas & Keputusan \\
\hline $\begin{array}{l}\text { Kecerdasan } \\
\text { Logis } \\
\text { Matematis }\end{array}$ & $\begin{array}{c}\text { Kemampua } \\
\mathrm{n} \\
\text { Komunikasi } \\
\text { Matematis }\end{array}$ & 2,586 & 0,045 & 11,074 & 1,997 & 0,000 & $H_{a}$ diterima \\
\hline $\begin{array}{l}F_{\text {hitung }}=122, \\
\mathrm{R}^{2}=0,67 \\
\alpha \quad=0,05\end{array}$ & & & & & & & \\
\hline
\end{tabular}

Berdasarkan Tabel 5 di atas, dapat diketahui bahwa nilai $t_{\text {hitung }}=11,074>t_{\text {tabel }}=$ 1,997 dengan tingkat probability $\mathrm{p}=0,000<0,05$, dengan demikian maka $H_{a}$ diterima dan $H_{0}$ ditolak. Sehingga dapat disimpulkan bahwa "ada hubungan yang signifikan antara kecerdasan logis matematis dengan kemampuan komunikasi matematis". Hasil estimasi dari hubungan variabel kecerdasan logis matematis dapat dinyatakan sebagai berikut:

$$
\begin{aligned}
& Y=a+b X \\
& Y=2,586+0,045 X
\end{aligned}
$$

Berdasarkan persamaan estimasi regresi di atas dapat dilihat nilai konsisten variabel kemampuan komunikasi matematis adalah sebesar 2,586. Koefesien regresi $X$ sebesar 0,045 bahwa setiap penambahan $1 \%$ nilai kecerdasan logis matematis maka nilai kemampuan komunikasi matematis bertambah sebesar 0,045. Koefesien regresi tersebut bernilai positif, sehingga dapat disimpulkan hubungan variabel kecerdasan logis matematis terhadap kemampuan komunikasi

Alifmatika: Jurnal Pendidikan dan Pembelajaran Matematika, Desember 2020, Vol. 2, No. 2 
matematis adalah positif. Sedangkan untuk koefesien determinasi (KD) hubungan antara variabel tersebut adalah 67,1\%. Hal ini menunjukkan bahwa $67,1 \%$ kemampuan komunikasi matematis siswa dapat dijelaskan oleh kecerdasan logis matematis, sementara sisanya sebesar 32,9\% dapat dijelaskan oleh faktor lain yang tidak dibahas dalam penelitian ini, seperti halnya motivasi belajar, banyak waktu belajar, dan lain-lain.

\section{PEMBAHASAN}

Pembahasan hasil penelitian ini akan dijabarkan tentang hasil dari analisis baik secara deskriptif dan inferensial yang diperoleh melalui penelitian sebagaimana berikut:

1. Kecerdasan Logis Matematis Siswa Kelas X

Berdasarkan hasil kecerdasan logis matematis siswa yang didapatkan melalui instrumen angket yang diberikan kepada siswa dengan jumlah 22 item pernyataan menunjukkan bahwa tingkat kecerdasan logis matematis siswa kelas X IPA SMAN Jenggawah Jember berada dalam kategori rendah (42-51) sebesar 15,63\% sebanyak 10 siswa, kategori sedang (52-61) sebesar 53,12\% sebanyak 34 siswa dan kategori tinggi (62-72) sebesar 31,25\% sebanyak 20 siswa.

2. Kemampuan Komunikasi Matematis Siswa Kelas X

Berdasarkan hasil kemampuan komunikasi matematis siswa yang didapatkan melalui instrumen tes yang diberikan kepada siswa dengan jumlah 22 item pernyataan menunjukkan bahwa tingkat kemampuan komunikasi matematis siswa kelas X IPA SMAN Jenggawah Jember berada dalam kategori rendah (018) sebesar 3,12\%, sebanyak 2 siswa, kategori sedang (19-37) sebesar 50,57\% sebanyak 33 siswa dan kategori tinggi (38-56) sebesar 45,31\% sebanyak 29 siswa.

3. Hubungan antara Kecerdasan Logis Matematis dan Kemampuan Komunikasi Matematis Siswa dalam Menyelesaikan SPLTV

Hasil penelitian ini menunjukkan bahwa ada hubungan yang signifikan antara kecerdasan logis matematis dan kemampuan komunikasi matematis. Hasil regresi linear sederhana dapat ditunjukkan dalam Tabel 6 berikut:

Tabel 6. Hubungan Kecerdasan Logis Matematis dan Kemampuan Komunikasi Matematis

\begin{tabular}{ccccc}
\hline Variabel & $t_{\text {hitung }}$ & $t_{\text {tabel }}$ & Sig. & Keterangan \\
\hline $\begin{array}{c}\text { Kecerdasan Logis } \\
\text { Matematis }\end{array}$ & 11,074 & 1,997 & 0,000 & Signifikan \\
\hline
\end{tabular}

Berdasarkan hasil analisis data pada Tabel 6 di atas, dapat ditunjukkan bahwa terdapat hubungan positif dan signifikan antara kecerdasan logis matematis dengan kemampuan komunikasi matematis siswa dalam menyelesaikan sistem persamaan linear tiga variabel (SPLTV) kelas X IPA di SMA Negeri Jenggawah. Hal

Alifmatika: Jurnal Pendidikan dan Pembelajaran Matematika, Desember 2020, Vol. 2, No. 2 
ini berarti semakin tinggi kecerdasan logis matematis siswa maka semakin tinggi kemampuan komunikasi matematis siswa. Hal ini dibuktikan secara statistika dengan hasil $t_{\text {hitung }}=11,074>t_{\text {tabel }}=1,997$ dengan $\mathrm{p}=0,000<0,05$. Sehingga dapat disimpulkan bahwa ada hubungan yang signifikan antara kecerdasan logis matematis dengan kemampuan komunikasi matematis siswa. Besarnya prosentase hubungan antara kedua variabel tersebut sebesar 67,1\%. Hal ini menujukan bahwa kecerdasan logis matematis memiliki keterkaitan terhadap naik turunya kemampuan komunikasi matematis siswa. Apabila kecerdasan logis matematis siswa tinggi maka kemapuan komunikasi matematis siswa juga tinggi. Begitupun sebaliknya, apabila kecerdasan logis matematis rendah maka kemampuan komunikasi matematisnya juga rendah. Hasil penelitian ini secara tidak langsung telah mendukung hasil penelitian yang dilakukan oleh Basuki (2015) bahwa terdapat pengaruh yang signifikan dari kecerdasan logis matematis dan kemandirian belajar terhadap hasil belajar matematika. Hasil belajar matematika dipengaruhi oleh faktor kecerdasan logis matematis dan kemandirian belajar sebesar 68,0\% dan faktor lainnya sebesar 32,0\%. Selain itu, terdapat hasil penelitian lain lagi yang didukung oleh hasil penelitian ini yaitu penelitian yang dilakukan oleh Probondani (2016) menjelaskan bahwa terdapat pengaruh yang signifikan dari kecerdasan logis matematis terhadap kemampuan komunikasi matematis sebesar $18,76 \%$ sedangkan $81,24 \%$ ditentukan oleh faktor lain.

Hasil penelitian tentang adanya hubungan kecerdasan logis matematis dan kemampuan komunikasi matematis siswa sejalan dengan pendapat Lwin, Khoo, Lyen, \& Sim (2008), karena orang berkecerdasan logis matematis memiliki kemampuan lebih dalam menangani bilangan dan perhitungan, pola, pemikiran logis dan ilmiah. Meskipun berkaitan dengan angka, kecerdasan logis matematis tidak berpusat dalam perhitungan angka secara terus menerus melainkan juga mengenai kemampuan komunikasi matematika secara tulisan.

Tidak dapat dipungkiri bahwa pada prisnsipnya siswa yang memiliki kecerdasan logis matematis itu akan mudah dalam menyelesaikan soal cerita matematika karena siswa mampu memahami dan menerjemahkan maksud dari soal cerita matematika tersebut, siswa mampu berfikir dengan angka, perhitungan, dan menarik kesimpulan dari hubungan secara logis, pemecahan masalah, dan memahami lambang dan simbol abstrak. Hasil penelitian ini memperkuat pernyataan yang diungkapkan oleh Gartmann \& Freiberg (Abidin \& Tohir, 2019), yang menjelaskan bahwa dalam pemecahan masalah terdapat proses menyadari dan mengatur berpikir tentang bagaimana siswa membuat pendekatan terhadap masalah, memilih strategi yang digunakan untu kmenemukan pemecahan dan bertanya kepada diri sendiri tentang masalah tersebut. Hasil penelitian ini juga

Relevan dengan dengan pendapat yang diungkapkan oleh Tohir, Susanto, Hobri, Suharto, \& Dafik (2018) bahwa "through the guidance of this mathematics, students are expected to have logical, analytical, systematic, critical, and creative, and has a good ability to work together". Kemudian juga relevan dengan hasil penelitian yang dilakukan oleh Anggraena (2019) menjelaskan bahwa mata pelajaran matematika perlu diberikan kepada semua peserta didik mulai dari sekolah dasar, untuk membekali pesertadidik dengan kemampuan berpikir logis, analitis, sistematis, kritis, inovatif dankreatif, serta kemampuan bekerjasama.

Alifmatika: Jurnal Pendidikan dan Pembelajaran Matematika, Desember 2020, Vol. 2, No. 2 
Berdasarkan uraian bahasan di atas dapat diinterpretasikan bahwa siswa yang memiliki kecerdasan logis matematis tinggi cenderung akan lebih mudah memahami dan menyelesaikan permasalahan matematika yang dihadapi. Sebaliknya, siswa yang memiliki kecerdasan logis matematis rendah cenderung akan susah atau kesulitan untuk memahami ataupun menyelesaiakan suatu permasalahan matematika yang dihadapi tersebut. Dengan demikian kecerdasan logis matematis sangat penting dimiliki oleh setiap siswa, karena berimplikasi postif terhadap kemampuan komunikasi matematisnya.

\section{KESIMPULAN DAN SARAN}

Hasil penelitian ini dapat disimpulkan bahwa terdapat hubungan yang positif dan signifikan antara kecerdasan logis matematis dan kemampuan komunikasi matematis siswa kelas X IPA SMA Negeri Jenggawah Jember. Hal ini dapat dilihat dari hasil perhitungan analisis regresi linear sederhana dengan melihat hasil $t_{\text {hitung }}=11,074>t_{\text {tabel }}=1,997$ dengan $\mathrm{p}=0,000<0,05$, yang disimpulkan bahwa hipotesis diterima dengan kata lain bahwa terdapat hubungan antara kecerdasan logis matematis dengan kemampuan komunikasi matematis siswa. hubungan tersebut signifikan dengan sumbangsi prosentase koefisien determinasi sebesar $67,1 \%$. Siswa yang memiliki kemampuan berpkir logis tinggi cenderung mudah dalam memahami dan memecahkan masalah matematika, sedangkan siswa yang memiliki kemampuan berpikir logis sedang dan rendah cenderung mengalami kesulitan dan susah memahami dan memecahkan masalah matematika. Siswa yang memiliki kemampuan berpikir logis tinggi cenderung akan memiliki kemampuan komunikasi matematis tinggi, sedangkan siswa yang memiliki kemampuan komunikasi rendah maka ia juga cenderung akan memiliki kemampuan komunikasi matematis rendah.

Adapun beberapa saran penelitian yang dapat direkomendasikan, yaitu: (1) Bagi guru, khususnya guru matematika diharapkan dalam kegiatan pembelajaran matematika untuk menciptakan suatu proses pembelajaran yang dapat meningkatkan kecerdasan logis matematis siswa agar dapat membantu mereka dala memahami dan menyelesaikan soal-soal yang berhubungan dengan permasalahan matematika dan (2) bagi peserta didik, kecerdasan logis matematis memiliki hubungan dengan kemampuan komunikasi matematis siswa sehingga siswa-siswi diharapkan sering berlatih dala menyelesaikan soal-soal matematika berbentuk soal cerita dan sering melatih kemampuan kecepatan dalam berhitung. Selain kecerdasan logis matematis masih ada faktor lain yang memengarui kemampuan komunikasi matematis siswa. oleh karena itu, diharapkan untuk peneliti berikutnya agar mengembangkan penelitian ini untuk menemukan faktorfaktor lain yang dapat memengaruhi kemampuan komunikasi matematis soal cerita yang berguna untuk meningkatkan kualitas siswa-siswi didalam pembelajaran di sekolah. 


\section{DAFTAR PUSTAKA}

Abidin, Z., \& Tohir, M. (2019). Keterampilan Berpikir Tingkat Tinggi dalam Memecahkan Deret Aritmatika Dua Dimensi Berdasarkan Taksonomi Bloom. Alifmatika: Jurnal Pendidikan Dan Pembelajaran Matematika, 1(1), 44-60. https://doi.org/10.35316/alifmatika.2019.v1i1.44-60

Agustina, D., Kaniawati, I., \& Suwarma, I. R. (2017). Penerapan pembelajaran berbasis STEM (Science, Technology, Engineering and Mathematics) untuk meningkatkan kemampuan control of variable siswa SMP pada hukum Pascal. Prosiding Seminar Nasional Fisika (E-Journal), 6(1), SNF2017-EER.

Andreani, T. C. (2017). Pengaruh Kecerdasan Logis Matematis dan Kecerdasan Linguistik Terhadap Kemampuan Pemecahan Masalah Matematis Soal Cerita Aritmatika Spsial Kelas VII SMP Negeri 51 Jakarta. Skripsi, Universitas Kristen Indonesia.

Anggraena, Y. (2019). Pengembangan Kurikulum Matematika untuk Meningkatkan Kemampuan Siswa dalam Penalaran dan Pemecahan Masalah. Alifmatika: Jurnal Pendidikan Dan Pembelajaran Matematika, 1(1), 15-27.

Arikunto, S. (2009). Manajemen Penelitian. Jakarta: Rineka Cipta.

Basuki, A. T. (2015). Analisis Statistik dengan SPSS. Yogyakarta: Danisa Media. Tersedia Secara Online Juga Di: Https://Ekonometrikblog. Files. Wordpress. com/2018/12/statistik-dengan-spss. Pdf [Diakses di Singaraja, Bali, Indonesia: 19 Desember 2018], 1(1), 29-39.

Budiyanto, R. (2018). Pengaruh Kecerdasan Logis-Matematis terhadap Kemampuan Pemecahan Masalah Matematis Siswa pada Penyelesaian Soal Cerita Materi SPLDV. Artikel Skripsi Universitas Nusantara PGRI Kediri, 2-8.

Endriani, Y., Mirza, A., \& Nursang, A. (2017). Hubungan Antara Kecerdasan Emosional dengan Kemampuan Komunikasi Matematis. Jurnal Pendidikan Dan Pembelajaran Khatulistiwa, 6(11), 2-14.

Lwin, M., Khoo, A., Lyen, K., \& Sim, C. (2008). How to multiply your child's intelligence. Jakarta: Indeks.

Maswar, M. (2017). Analisis Statistik Deskriptif Nilai UAS Ekonomitrika Mahasiswa dengan Program SPSS 23 \& Eviews 8.1. Jurnal Pendidikan Islam Indonesia, 1(2), 273-292. https://doi.org/10.35316/jpii.v1i2.54

Mukarromah, L. (2019). Kecerdasan Logis Matematis Siswa dalam Menyelesaikan Masalah Matematika Melalui Problem Posing pada Materi Himpunan Kelas VII MTS Nurul Huda Mojokerto. Jurnal Penelitian, Pendidikan, Dan Pembelajaran, 14(8), 16-22.

Munawwarah, M., Laili, N., \& Tohir, M. (2020). Keterampilan Berpikir Kritis Mahasiswa dalam Memecahkan Masalah Matematika Berdasarkan Keterampilan Abad 21. Alifmatika: Jurnal Pendidikan Dan Pembelajaran Matematika, 2(1), 3758. https://doi.org/10.35316/alifmatika.2020.v2i1.37-58

Novitasari, D., \& Abdul Rahman, A. (2015). Profil Kreativitas Siswa dalam Pemecahan Masalah Matematika Ditinjau dari Kecerdasan Visual Spasial dan Logis Matematis

Alifmatika: Jurnal Pendidikan dan Pembelajaran Matematika, Desember 2020, Vol. 2, No. 2 
pada Siswa SMAN 3 Makasar. Daya Matematis: Jurnal Inovasi Pendidikan Matematika, 3(1), 41-50.

Probondani, S. D. (2016). Pengaruh kecerdasan logis-matematis terhadap kemampuan representasi matematis peserta didik kelas XI Madrasah Aliyah Wathoniyah Islamiyah Banyumas tahun ajaran 2015/2016 pada materi pokok Trigonometri. UIN Walisongo.

Saiful, S., Hobri, H., \& Tohir, M. (2020). Analisis Metakognisi Siswa Berbasis Lesson Study For Learning Community (LSLC) Ditinjau dari Gaya Kognitif. Alifmatika: Jurnal Pendidikan Dan Pembelajaran Matematika, 2(1), 73-91. https://doi.org/10.35316/alifmatika.2020.v2i1.73-91

Senjayawati, E. (2015). Penerapan Pendekatan Kontekstual untuk Meningkatkan Kemampuan Komunikasi Matematik Siswa SMk di Kota Cimahi. Didaktik, 9(1), 33-39.

Siagian, M. D. (2016). Kemampuan koneksi matematik dalam pembelajaran matematika. MES: Journal of Mathematics Education and Science, 2(1), 58-67.

Sugiyono. (2017). Metode Penelitian Kuantitatif, Kualitatif dan R\&D. Bandung: Alfabeta.

Tohir, M., Abidin, Z., Dafik, D., \& Hobri, H. (2018). Students Creative Thinking Skills in Solving Two Dimensional Arithmetic Series Through Research-Based Learning. Journal of Physics: Conference Series, $1008(1), \quad 012072$. https://doi.org/10.1088/1742-6596/1008/1/012072

Tohir, M., Maswar, M., Atikurrahman, M., Saiful, S., \& Pradita, D. A. R. (2020). Prospective teachers' expectations of students' mathematical thinking processes in solving problems. European Journal of Educational Research, 9(4), 1735-1748. https://doi.org/10.12973/eu-jer.9.4.1735

Tohir, M., Susanto, Hobri, Suharto, \& Dafik. (2018). Students' Creative Thinking Skills in Solving Mathematics Olympiad Problems Based on Problem-Solving Polya and Krulik-Rudnick Model. Advanced Science Letters, 24(11), 8361-8364. https://doi.org/10.1166/asl.2018.12563 